Шиян Галина Анатольевна

учитель

МБОУ «Средняя школа №4 им. А.М. Горького» г. Петропавловск-Камчатский, Камчатский край

DOI $10.21661 / r-508099$

\title{
АКТИВНЫЕ МЕТОДЫ ОБУЧЕНИЯ В ШКОЛЕ КАК ИНСТРУМЕНТ РЕАЛИЗАЦИИ ДЕЯТЕЛЬНОСТНОГО ПОДХОДА
}

Аннотация: в этой статье автор рассматривает важность и необходимость использования активных методов обучения, выполняющих направляющую, обогащающую, систематизирующую роль в умственном развитии детей, способствующих активному осмыслению знаний. Активизация познавательной деятельности обучаюшихся - актуальнейшая проблема современности.

Ключевые слова: активизачия познавательной деятельности, технология активного обучения, активные методы обучения.

Стремительно развивающиеся изменения в обществе и экономике требуют сегодня от человека умения быстро адаптироваться к новым условиям, находить оптимальные решения сложных вопросов, проявляя гибкость и творчество, не теряться в ситуации неопределенности, уметь налаживать эффективные коммуникации с разными людьми и при этом оставаться нравственным.

Каждому человеку, вступающему в наш сложный и противоречивый мир, необходимы определенные навыки мышления и качества личности. Умение анализировать, сравнивать, выделять главное, решать проблему, способность к самосовершенствованию и умение дать адекватную самооценку, быть ответственным, самостоятельным, уметь творить и сотрудничать - вот с чем ребенку необходимо войти в этот мир.

Задача школы - подготовить выпускника, обладающего необходимым набором не только современных знаний, умений, но и качеств, позволяющих ему уверенно чувствовать себя в самостоятельной жизни. Для их решения требуются 
новые педагогические технологии, эффективные формы организации образовательного процесса, активные методы обучения.

Важнейшим средством активизации личности в обучении выступают активные методы обучения (AMO) - система методов, обеспечивающих активность и разнообразие мыслительной и практической деятельности обучающихся в процессе освоения учебного материала; это форма взаимодействия обучающихся и учителя, обеспечивающая многоуровневую и разностороннюю коммуникацию всех участников образовательного процесса, при которой учитель и обучающиеся взаимодействуют друг с другом в ходе урока и обучающиеся здесь не пассивные слушатели, а активные участники урока.

Активное обучение предполагает использование такой системы методов, которая направлена главным образом на самостоятельное овладение обучающимися знаниями и умениями в процессе активной мыслительной и практической деятельности.

Особенности активных методов обучения состоят в том, что в их основе заложено побуждение к практической и мыслительной деятельности, без которой нет движения вперед в овладении знаниями.

К активным методам обучения относятся методы, использующиеся внутри образовательного мероприятия в процессе его проведения. Для каждого этапа урока используются свои активные методы, позволяющие эффективно решать конкретные задачи конкретного этапа урока.

АМО строятся на практической направленности, игровом действие и творческом характере обучения, интерактивности, разнообразных коммуникациях, использовании знаний и опыта обучающихся, групповой форме организации их работы, вовлечении в процесс всех органов чувств, деятельностном подходе к обучению, движении и рефлексии

Основные активные методы обучения:

1. Проблемное обучение. Учебная деятельность уподобляется научному поиску и отражается в понятиях: проблема, проблемная ситуация, гипотеза, средства решения, эксперимент, результаты поиска. Достоинства проблемного 
обучения: развивает мыслительные способности обучающихся, интерес к учению, творческие силы.

2. Метод кейс-стади (метод анализа конкретных ситуаций). Для организации обучения используются описания конкретных ситуаций (от англ. «сase»случай). Обучающимся предлагают осмыслить реальную жизненную ситуацию, описание которой одновременно отражает не только какую-либо практическую проблему, но и актуализирует определенный комплекс знаний, который необходимо усвоить при разрешении данной проблемы. При этом сама проблема не имеет однозначных решений.

3. Деловая игра. Творческая активность личности в деловых играх стимулируется тем, что игра позволяет ощутить значимость своего «Я». Закомплексованность и скованность на основе интереса сменяются активностью, собранностью. Этот интерес вызывает положительные эмоции, задает творческую направленность личности, увеличивает темпы и результаты эвристического мышления. В процессе игры наиболее полно реализуется один из важнейших принципов воспитания - принцип единства знаний и опыта.

4. Семинар-дискуссия (групповая дискуссия). Это процесс диалогического общения участников, в ходе которого происходит формирование практического опыта совместного участия в обсуждении и разрешении теоретических и практических проблем, что вызывает интерес и положительные эмоции, задает творческую направленность личности, увеличивает темпы и результаты эвристического мышления.

5. «Кругльй стол» - это одна из организационных форм познавательной деятельности обучающихся, позволяющая закрепить полученные ранее знания, восполнить недостающую информацию, сформировать умения решать проблемы, укрепить позиции, научить культуре ведения дискуссии. Наряду с активным обменом знаниями, у обучающихся вырабатываются профессиональные умения излагать мысли, аргументировать свои соображения, обосновывать предлагаемые решения и отстаивать свои убеждения. При этом происходит 
закрепление информации и самостоятельной работы с дополнительным материалом, а также выявление проблем и вопросов для обсуждения.

6. «Мозговой штурм» - один из наиболее часто используемых методов стимулирования творческой активности, позволяющий найти решение какой-либо сложной проблемы. Основной принцип мозгового штурма заключается в том, что никто не должен высказывать оценку или критику в адрес любой идеи, возникшей в ходе обсуждения. Метод мозгового штурма предполагает, что каждый человек в какой-то степени обладает творческими способностями. В ходе мозгового штурма все ограничения убираются, и потенциал может быть использован в полной мере.

Данная технология представляется как средство стимулирования интеллектуальных творческих способностей, при котором участникам работы предлагается высказывать как можно больше вариантов решения, в т.ч. самых фантастических.

Кроме интенсификации освоения учебной информации, эффективно использование AMO в воспитательном процессе. Работа в команде, отстаивание своей позиции и толерантное отношение к чужому мнению, принятие ответственности за себя и команду, способность принимать решения и умение решать проблемы, формируют качества личности, отвечающие современным потребностям общества.

Активные методы обеспечивают решение образовательных задач в разных аспектах:

- АМО формируют положительную учебную мотивацию;

- повышают познавательную активность обучающихся;

- активно вовлекают всех школьников в образовательный процесс;

- стимулируют самостоятельную деятельность;

- помогают эффективно усваивать большой объем учебной информации;

- развивают творческие способности, нестандартность мышления, коммуникативно-эмоциональную сферу обучающегося; 
- раскрывают личностно-индивидуальные возможности каждого обучающегося и определяют условия для их проявления и развития.

Вывод.

Активные методы обучения выполняют направляющую, обогащающую, систематизирующую роль в умственном развитии детей, способствуют активному осмыслению знаний.

Технология активного обучения - это обучение, соответствующее силам и возможностям школьников. Важно также отметить, что передача обучающимся части полномочий по освоению образовательной программы, признание их значимой роли в достижении успеха обучения, а также учет психофизиологических особенностей школьников при проектировании и осуществлении обучения и воспитания меняет в положительную сторону отношение обучающихся к учителю и к образовательному процессу, что, в свою очередь, приводит к созданию благоприятного климата в классе и школе, содействуя успешному выполнению стоящих перед школой целей.

Активизация познавательной деятельности обучающихся - актуальнейшая проблема современности. Игровая форма разбора и презентации материала, возможность двигаться и разговаривать в процессе обсуждения заданий, подключение творчества при подготовке презентации, соревнование команд, азарт, значительная доля самостоятельности на уроке, ответственность за правильность представления материала и усвоения его другими - все это вызывает активизацию обучающихся.

Применение AMO эффективно в различных видах и формах деятельности с обучающимися, способствующая развитию коммуникативных способностей, активизации познавательного интереса учащихся, а также развитию творческого потенциала.

\section{Сиисок литературы}

1. Лазарев Т.В. Образовательные технологии новых стандартов: настольная книга современного педагога. Ч.1: Технология АМО / Т.В. Лазарев. - Петрозаводск: Verso, 2012. - 555 с. 
2. Образовательный портал «Мой университет» [Электронный ресурс]. Режим доступа: http://www.moi-universitet.ru/

3. Гибш И.А. Активность учащихся как условие, необходимое для повышения качества обучения / И.А. Гибш. - М., 1961.

4. Смолкин А.М. Методы активного обучения / А.М. Смолкин. - М., 1991. $90 \mathrm{c}$.

5. Шумова И.В. Активные методы обучения как способ / И.В. Шумова // Молодой ученый. - 2011. - С. 57-61. 